Javier Pérez Igualada, Int. J. Sus. Dev. Plann. Vol. 11, No. 2 (2016) 97-106

\title{
WATER-SENSITIVE STRATEGIES IN THE NEW URBAN PARKS IN VALENCIA: THE AGRICULTURAL MEDITERRANEAN PARADIGM AS A PATTERN FOR LANDSCAPE MANAGEMENT AND DESIGN
}

\author{
JAVIER PÉREZ IGUALADA \\ Department of Urbanism. Polytechnic University of Valencia.
}

\begin{abstract}
The paper shows how some water-sensitive strategies that have traditionally been used in Mediterranean agriculture to manage rainwater reappear as basic elements in the design of the main urban parks built in recent years in the city of Valencia, as Cabecera Park, Hesperides Garden, Marxalenes Park and Central Park. The elements associated with the use of the water for agricultural purposes in the Mediterranean context, as canals, ditches, irrigation ponds and cisterns, as well as the terrain modeling with terraces to retain rainwater, are some of the archetypal elements that compose a distinctive anthropic landscape, and provide, in addition to tested solutions for an efficient water management, a set of morphological patterns to design these new parks.
\end{abstract}

Keywords: landscape architecture, mediterranean agriculture, sustainable urban drainage systems, urban parks, valencia, water-sensitive urban design.

\section{WATER MANAGEMENT IN MEDITERRANEAN AGRICULTURAL LANDSCAPES}

Water is a scarce and valuable resource, especially in the Mediterranean area. In recent times, as a result of the growing environmental awareness, water strategy is not considered uniquely as a hygienic-sanitary and engineering problem associated with the performance of infrastructure networks and supply and evacuation facilities, but also from a more general approach, which incorporates qualitative aspects such as those relating to landscape adequacy and integration of urban and natural processes. This has led to alternative solutions for the management of rainwater, as the so-called sustainable urban drainage systems.

To promote permeability and infiltration, to reduce pollution of rivers as a result of minimising urban runoff, and to contribute to the re-composition of pre-urbanization hydrological conditions where possible, are key aspects for an efficient water management [1], and have important implications in the design of urban green spaces, not only regarding water supply systems, irrigation and drainage, but also in terms of their physical configuration.

Canals, ditches, irrigation ponds and cisterns, as well as the terrain modeling with retention walls to configure terraces and retain rainwater, are some of the archetypal elements traditionally associated with the use of the water for agricultural purposes in the Mediterranean context [2]. These elements provide historically tested solutions for an efficient water management, and compose a distinctive anthropic landscape (Figs 1 and 2), where geometry has an important presence. 


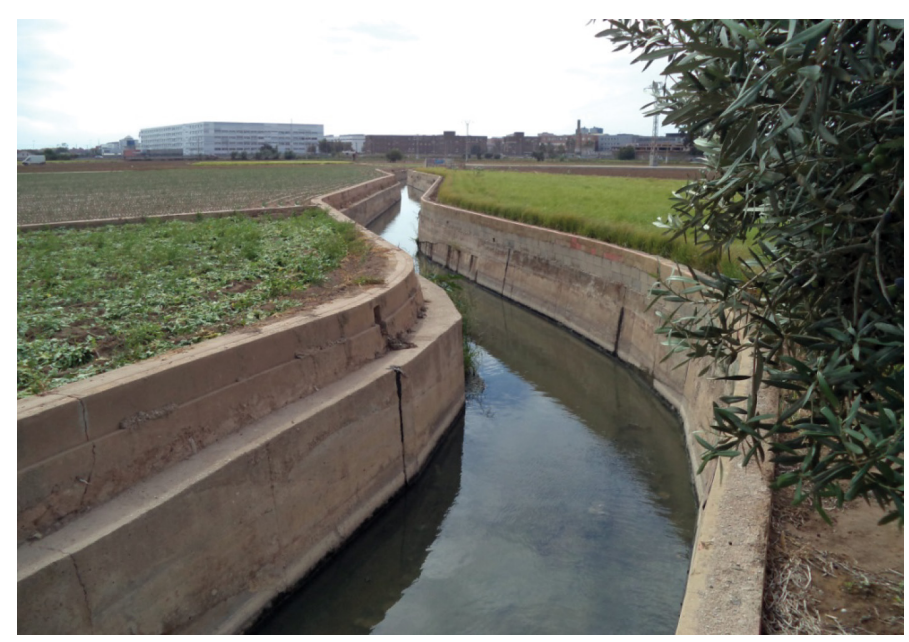

Figure 1: Community-operated watercourse for irrigation. Mestalla canal (acequia), northern irrigated area (huerta), Valencia.

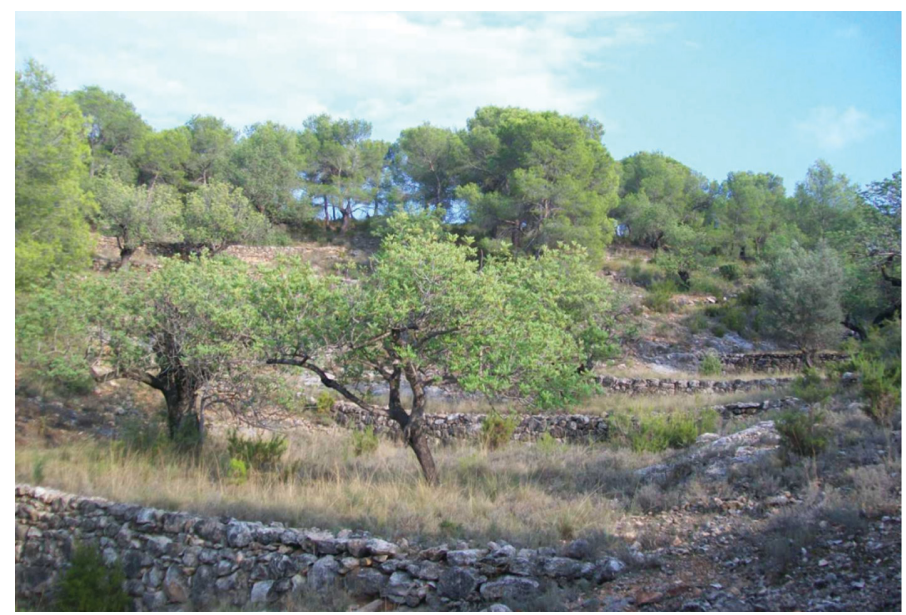

Figure 2: Terrain modeling with dry stone retention walls, creating terraces to retain rainwater. Sierra Calderona, Valencia.

Agriculture, as a cultural landscape, implies geometry. Grooves are parallel straight lines, trees are planted in alignment or grid, and farmlands are rectangles or trapezoids, making up a mosaic at a territorial scale. Retaining walls, pools or cisterns and irrigation canals, are also elements whose geometry demonstrates its artificial nature of human work (Fig. 3). Farmers do not seek to imitate nature, but to transform it in a rational way, to obtain food and energy.

These two aspects, its efficient water management and its character of cultural landscape, shaped by geometry, make the Mediterranean agricultural landscape a fundamental reference, able to provide a set of morphological patterns for the new green urban landscapes. 


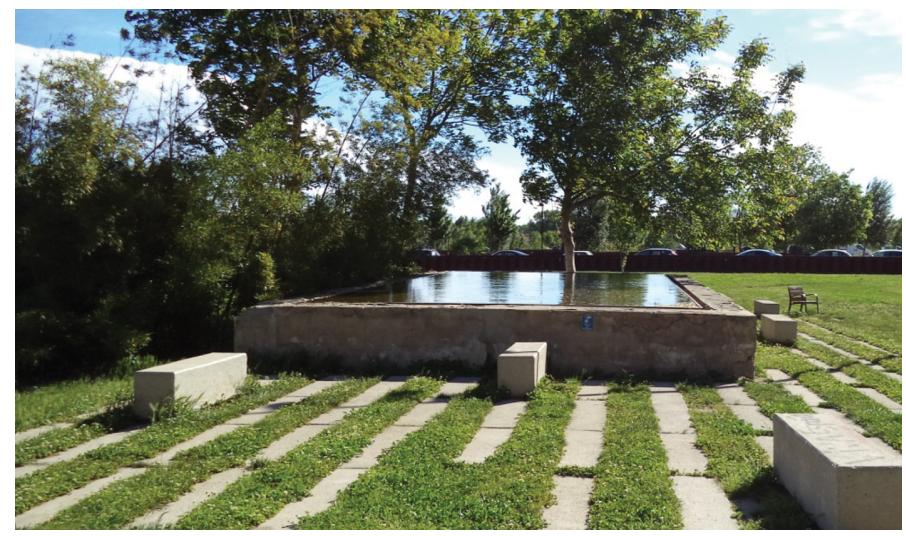

Figure 3: Agricultural irrigation basin reused in a public green space. Water Park (Parc de les Aigües), Figueres. Michelle \& Miquel, landscape architects.

\section{AGRICULTURAL ARCHETYPES AS DESIGN PATTERNS IN THE NEW URBAN PARKS IN VALENCIA}

The agricultural Mediterranean paradigm has been used as a pattern for landscape management and design in some of the main urban parks built in recent years in the city of Valencia [3]. We will examine here how traditional water-sensitive strategies and archetypes from the Mediterranean agriculture reappear as basic elements in the design of those parks.

\subsection{Landform: retention walls and terraced landscapes}

Terrain modeling is associated with agriculture since ancient times, as modifying the original topography of the site is usually necessary to introduce productive uses on it. In agriculture, retention walls allow the staggering of the slopes, creating horizontal terraces for crops, where rain and irrigation water are filtered into the ground and used to grow plants, avoiding both water waste and surface soil erosion. Terraced landscapes have thus a relevant environmental role related to hydric control, overlapped to its role as cultural heritage associated with agriculture and identity reference of a territory.

The design of open spaces involves also a terrain modeling in sloped sites, although terraces in this case are not necessary for crops but for recreational purposes. The retention walls are, as in agriculture, the elements that structure open spaces and organize their artificial topography, making them accessible and usable to the public.

An example of this is the Cabecera Park (2001-04), a green space located in the west end of the Gardens of the river Turia, a great linear urban park that traverses the entire city and occupies the original riverbed course, which remained free since a new artificial hydraulic channel and a new mouth were built to prevent the floods, diverting Turia's riverbed to the south.

The Cabecera Park [4] recreates the original landscape of the river Turia, through a design concept that does not seek a mimetic copy but an architectural interpretation of that landscape. The terrain modeling plays a central role in the overall composition of Cabecera Park (Fig. 4). Using dry stone retaining walls similar to those we can find in Mediterranean agriculture, the site is structured in horizontal terraced surfaces where ordinary rains gener- 


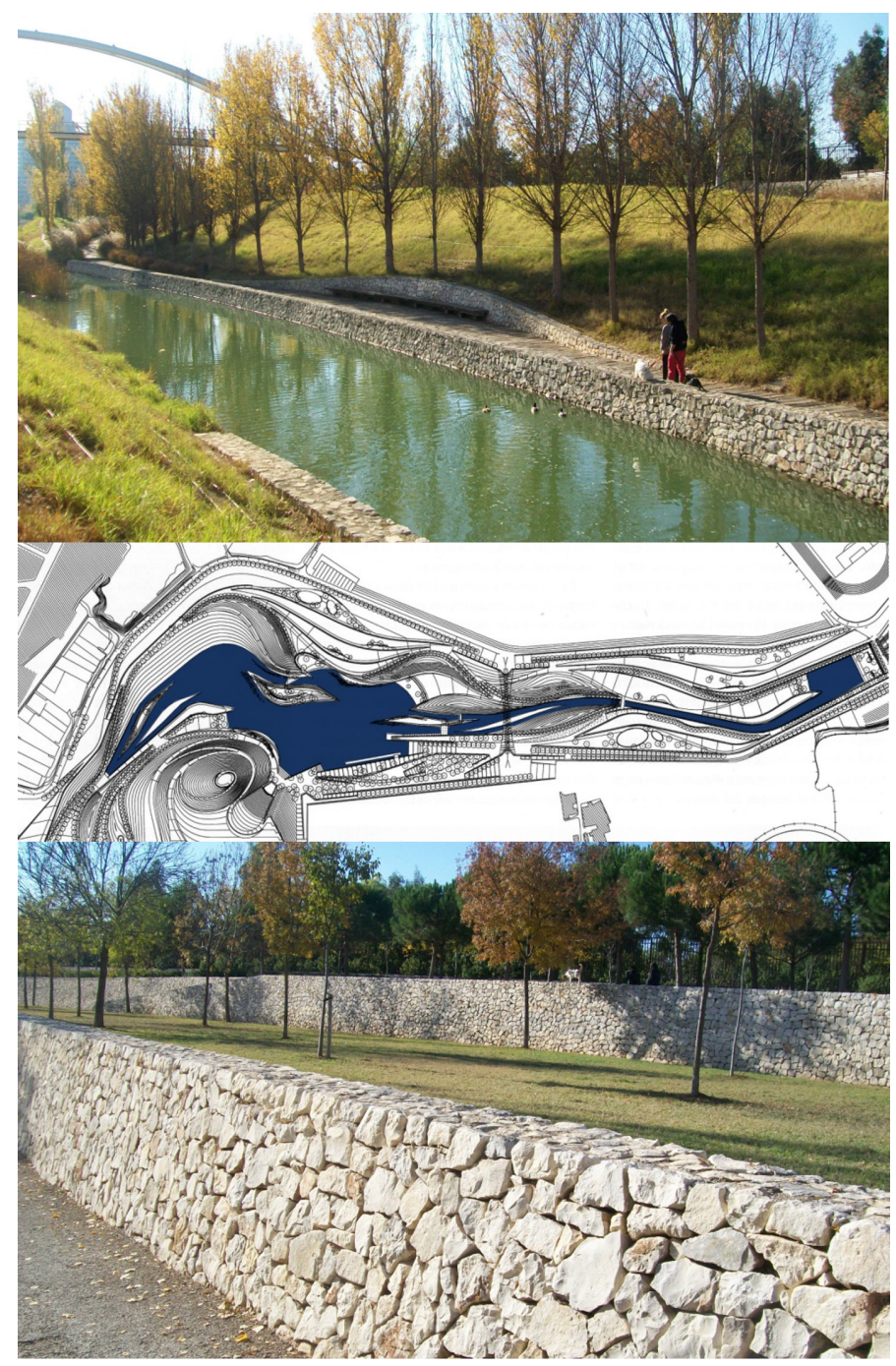

Figure 4: Header Park (Parque de Cabecera). Turia Garden, Valencia. Authors: A. Muñoz, E. de Miguel, V. Corell, 2001-2004.

ate little or no runoff, as these are retained by the pervious plant coverage and infiltrated in the ground. Dry stone walls are also used in water canals banks and as a plinth for green slopes.

Dry stone walls have been widely used in the Mediterranean regions as retaining walls to configure terraced spaces for agro forestry purposes. That has resulted in huge extensions of anthropic landscape units, whose cataloging is being carried out through European programs as PATTER or ALPTER [5]. Both in agriculture and in urban parks, dry stone retention walls are a sustainable construction technique: they are built with stone, a local material readily available and easy to recycle, with natural drainage, as the joints are not filled with mortar. 


\subsection{Plant material and irrigation: huertas, acequias and albercas}

The Spanish words acequia and alberca come from the Arabic ('as-sāqiya' and 'albírka'), because the irrigation technology associated with these terms was a contribution of the Hispanic Arabic culture to agriculture and gardening, brought to the Iberian peninsula in the Middle Age.

An acequia is a watercourse that operates for gravity, used in agriculture to channel water for surface irrigation systems. It can be a simple open ditch, a concrete-lined ditch or even a pipe or an aqueduct. An alberca is a water retention pond which is part of the network of acequias, and can be dug on land or built with brick or masonry, usually with a rectangular plan. From antiquity, albercas have also been used for ornamental and recreational use.

The Valencian huerta is an historic agricultural territory around the city that has been irrigated for centuries by a network of acequias that take water from the river Turia. The low retention wall that allows the level of the river to be raised slightly and to divert part of the flow to the acequias is called in Spanish azud ('as sad' in Arabic).

Both acequias and albercas can act occasionally as drainage elements in case of heavy rainfall, and collected precipitations can be used to irrigate plantations.

The small and delightful Hesperides Garden (1998-2000) is one of the new urban green spaces built in Valencia that shows how water management for public recreational uses can be implemented by means of traditional acequias and albercas, combined with other elements also derived from agricultural archetypes, such as linear geometry, terraced landform, pervious paving and a selection and arrangement of vegetal material in agreement with the patterns of orchards.

Adjacent to the Botanic Garden of Valencia, the Hesperides Garden [6] is conceived as an 'hortus conclusus', an enclosed garden that houses in its west side a collection of citrus, set out in linear beds that configure three staggered terraces facing a central esplanade made of red granular paving (Fig. 5).

Citric orchards such as orange and lemon trees made Valencian horticulture renowned in fifteenth-century Europe. The collectible character proposed for the Hesperides Garden merges gardening, agricultural and botanic approaches to plant selection and site design.

Water appears in this garden in the two main forms used in Mediterranean agriculture: as flowing water in acequias and as still water in albercas. After springing up from a fountain in the highest point of the garden, water flows down through irrigation gutters along the terraces of citrus and descends in a staggered way to the esplanade level, crossing it through an underground pipe to emerge in the rectangular artificial sink of the alberca.

Marxalenes Park (1998-2001) is another new urban green space in Valencia where huertas, acequias and albercas are used as main elements of water management and landscape design [7]. The northern area of this district park is designed as homage to the 'huerto', an essential part of the private Valencian gardens of XIX century, which was the place to cultivate vegetables and fruit trees for personal consumption, as well as herbs and medicinal plants.

The layout of the huertas in Marxalenes Park has a distinctive geometric character (Fig. 6), as it is formed by a grid of square plantation beds for flower beds, herbs and aromatic and medicinal plants, surrounded by acequias designed as small concrete-lined irrigation gutters which are fed by a large basin. Fruit trees are arranged around the beds in an orchard grid pattern. 

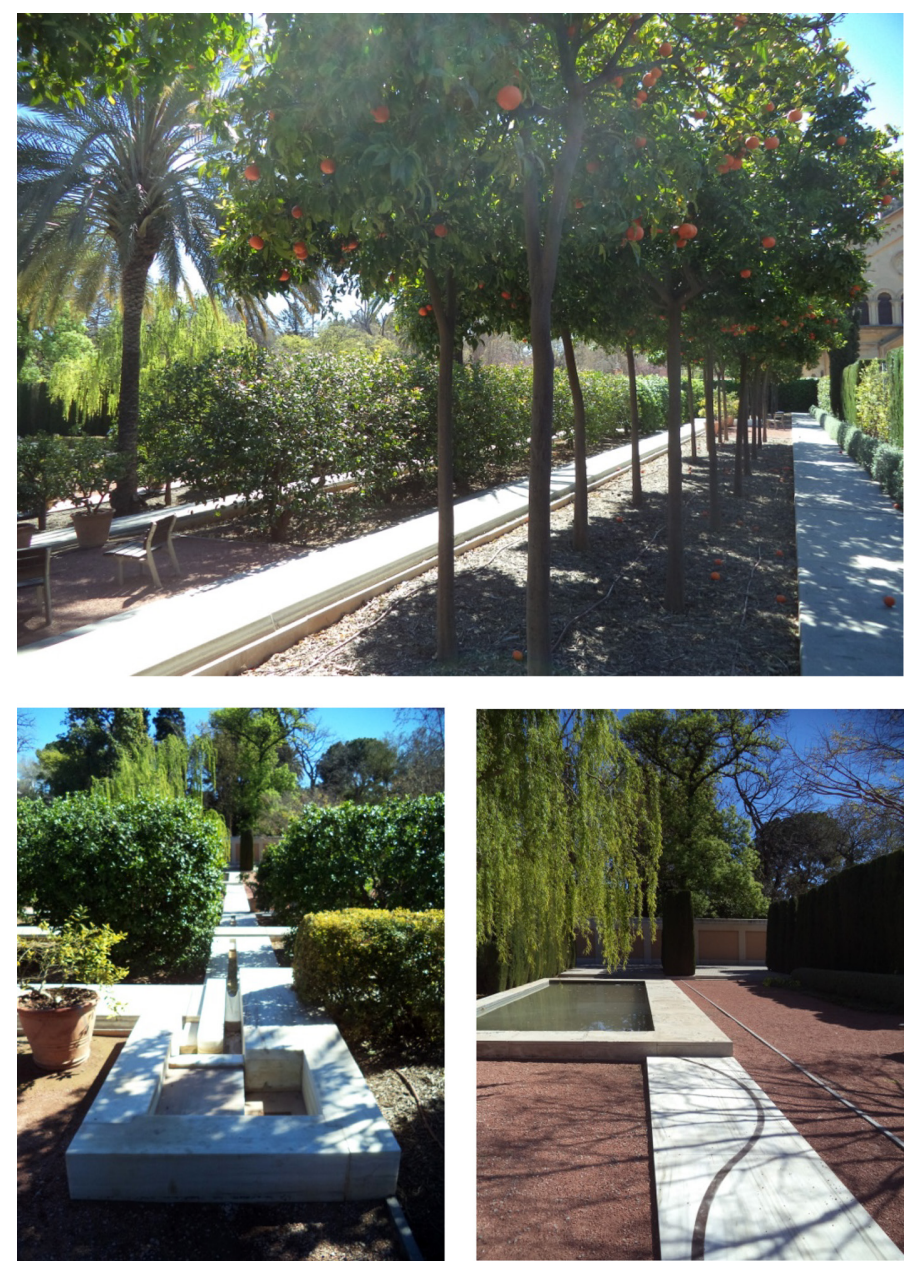

Figure 5: Hesperides Garden, Valencia, 1998-2000. Authors: M.T. Santamaría, A. Gallud, C. Campos, M. del Rey.

The design of the open spaces in Sociopolis, a new residential neighborhood located on a site on the edge of the city of Valencia, in the south huerta, represents a step forward in the relationship between agricultural patterns and urban landscape design. Sociopolis masterplan is in fact a proposal to inhabit the huerta, where green spaces integrate agriculture as a basic element. Instead of recreational urban parks, with only ornamental plantations, we can find here a new kind of open spaces that we might call 'agricultural green urban spaces', which can be exploited as productive land and can be considered at the same time as true urban open spaces. These agricultural green urban spaces can be managed with historically tested agricultural techniques, and can also promote new types of leisure activities in public spaces (Fig. 7).

Sociopolis is thus an attempt to break out the city-country dichotomy, creating what its authors have called 'rurban' territories that result in an integration of the agricultural culture of the huerta into the city [8]. 

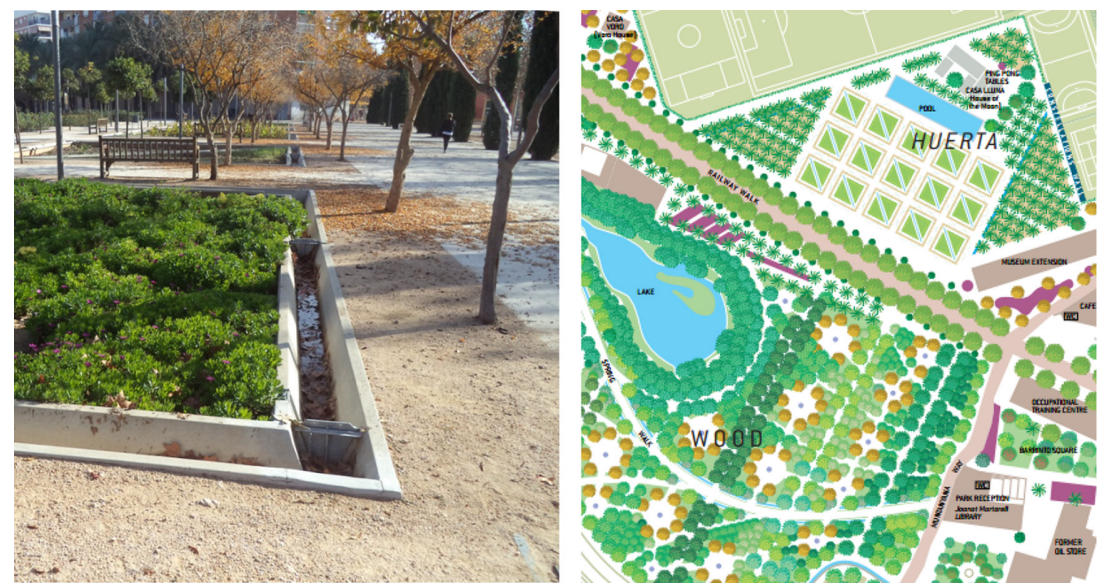

Figure 6: Marxalenes Park, Valencia, 1998-2001. Authors: Amparo Medina Piles, Babilonia Gardening Workshop.

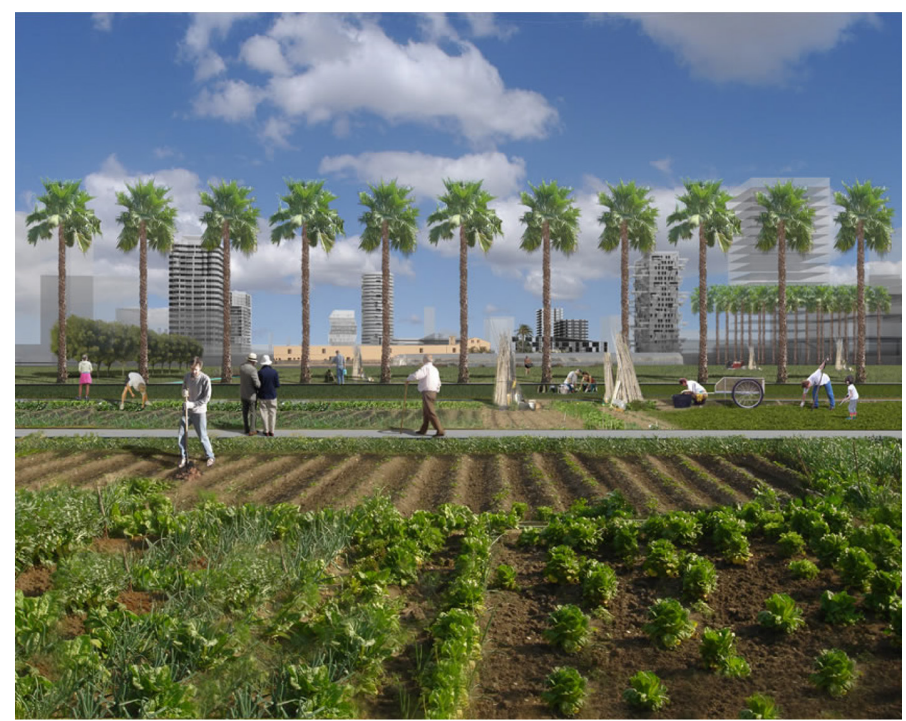

Figure 7: Agricultural green urban spaces. Sociopolis Masterplan, Valencia, 2002-10. Authors: Guallart Architects.

\subsection{Rainwater: sustainable drainage systems}

One key aspect of sustainable water management is rainwater drainage. Precipitations that fall on sealed surfaces such as roofs or open spaces must be collected to protect buildings and prevent flooding. In conventional drainage systems, rainfall is directed into the general sewage system. Water-sensitive drainage systems direct the surplus of rainwater back to the natural water cycle by means of evaporation or infiltration [9]. In an urban context, however, 
there are some restrictions to these systems: rainwater falling on pavements of streets or surfaces for road traffic cannot be infiltrated, because it may contaminate aquifers.

Valencia Central Park is the biggest of the new urban parks of the city, and covers a 23-hectare urban area now occupied by the central railway station. The public park, now in a first phase of construction, will be completed after the tunneling of the existing railway lines below ground (Fig. 8).

The design concept of the park is inspired by the Valencian culture of ceramics, and is based on the image of the 'bowl', as a metaphoric container for water, food, people, landscapes and history. One of this bowls is the Huerta Garden, located in the east side of the
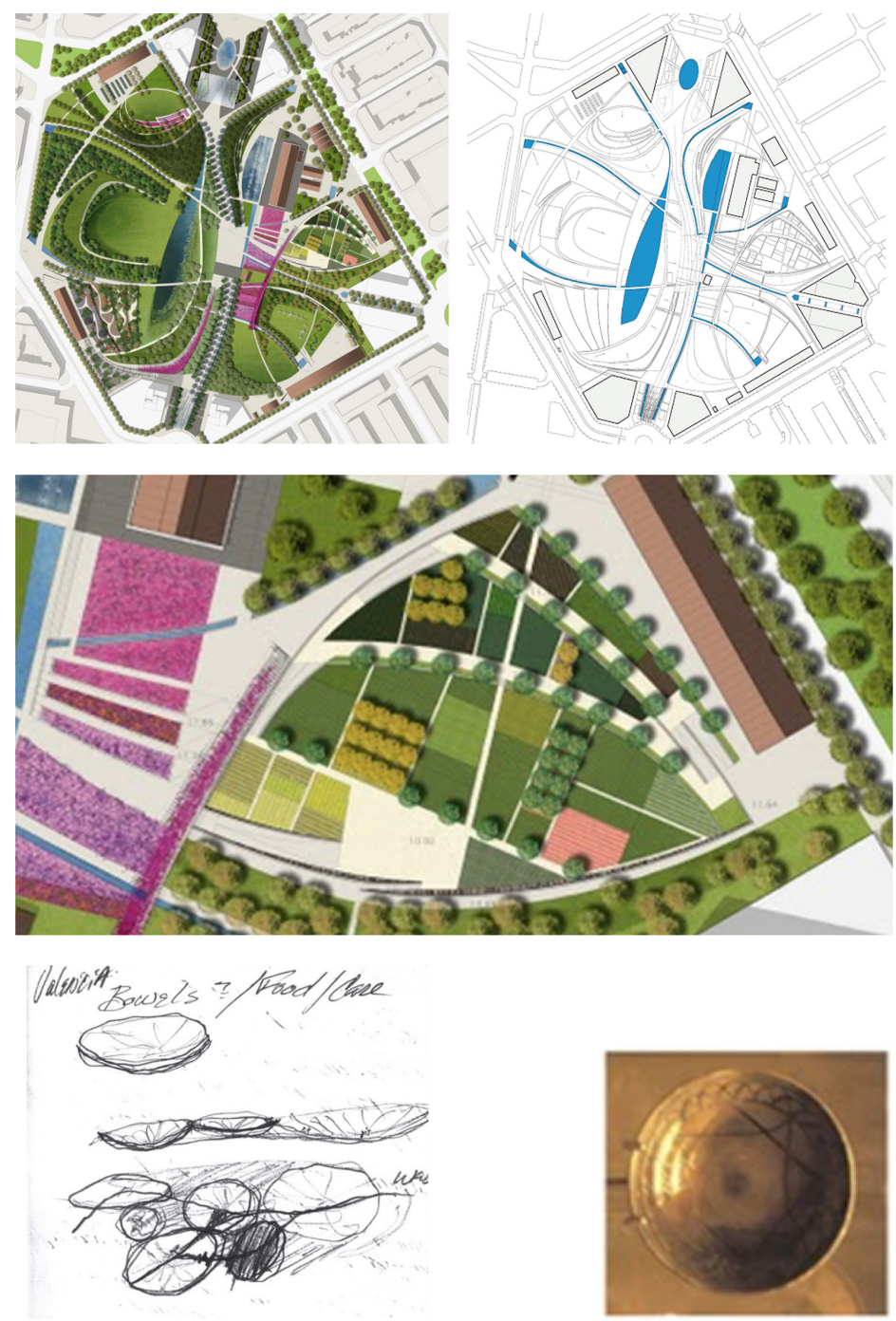

Figure 8: Valencia Central Park. Development project. Authors: Gustafson-Porter, Nova Ingeniería, Grupotec, Borgos Pieper. 
park, and configured as a series of planted terraces that recreate the agricultural landscape of the huerta. The plan of this section of the park shows the recognizable patchwork pattern of crop fields

In Valencia Central Park, water strategy has a main objective the reduction of water consumption. Water is a main element in the design, and adopts different forms: Urban water (treated), natural water (untreated), sources at the entrances, water channels on access roads, and special fountains at North and South piazzas.

The proposed strategy for sustainable drainage in Valencia Central Park is linked to the referred design concept of bowl, and consist on low-lying areas of different green surfaces that act as sinks of rainwater. These areas act also as a basin, as terrain modeling has been designed to create a slope from the perimeter towards the center of those low-lying areas.

Ordinary rain fall generates little or no runoff, as it will be retained by the plant surface coverage of the park and thus it will soak in the ground.

The elements that collect the surplus of rainwater are modular polypropylene tanks that have no visual impact as they are buried under 30 centimeters of topsoil (Fig. 9). These modular polypropylene tanks have a storage capacity corresponding to the runoff generated on the surface of each basin by a rain return period of 10 years.

\section{CONCLUSIONS}

Landscape design has historically used the lessons of agriculture, both translating images of the agricultural world to the urban parks, and introducing agricultural techniques in the construction of parks. We have pointed out some water- sensitive strategies used in the new urban parks built in Valencia, showing through case studies how agricultural Mediterranean paradigm reappears as a pattern for landscape management and design.

The detailed case studies analysis presented in the paper allows us to verify that through these design strategies urban green landscapes can share an ecological aesthetic with agricultural landscape archetypes, an aesthetic that involves land care, attachment and identity [10].

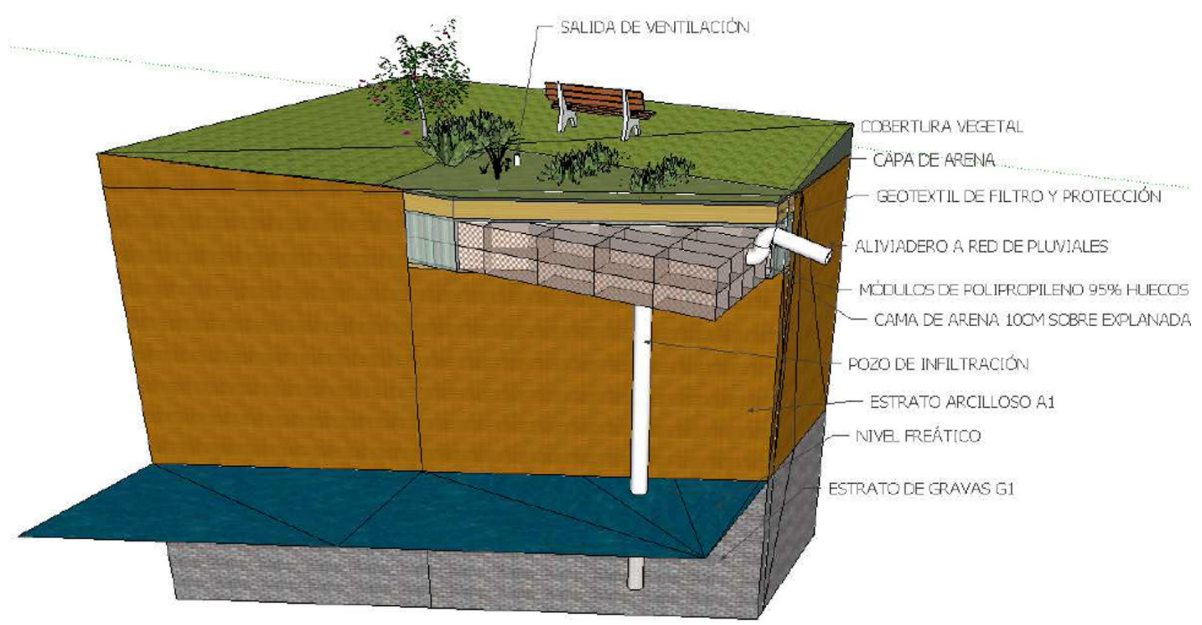

Figure 9: Valencia Central Park. Development project. 3d view of a modular polypropylene infiltration tank. Authors: Gustafson-Porter, Nova Ingeniería, Grupotec, Borgos Pieper. 
Furthermore, some of the case studies show, as Batlle [11] has stated, that if agriculture is in the origins of the garden, it's reasonable to think that, after a period of maximum artificiality and loss of origins in landscape design, the garden may return to agriculture, recovering the horticultural character of its primordial images.

\section{REFERENCES}

[1] AA.VV., Criterios para una jardinería sostenible en la ciudad de Madrid, Ayuntamiento de Madrid: Madrid, 184, 2007.

[2] Navés, F., Arosamena, G., Ruiz, B., Martínez, C., García, R. \& Sampere, L., Arquitectura del paisaje rural de la Península Ibérica, Islas Baleares y Canarias, Omega: Barcelona, 2005.

[3] Medina, A. (ed), Guía de jardines históricos y parques urbanos, Ayuntamiento de Valencia: Valencia, 2009.

[4] De Miguel, E., Muñoz, A. \& Corell, V., Parque de Cabecera. AV Monografías, 111(112), pp. 112-117, 2005.

[5] Alomar, G., Ferrer, I., Grimalt, M., Reynes, A. \& Rodríguez, R., El programa europeu PATTER. Una metodología de catalogació d'espais de marjades aplicable a l'entorn sudeuropeu. Dovella, 78, pp. 31-34, 2002.

[6] Santamaría, M.T., Gallud, A., Campos, C. \& Del Rey, M., Jardín de las Hespérides. ViA arquitectura, 9, pp. 40-46, 2001.

[7] Mangue, I., Marxalenes: de alquería islámica a barrio de la ciudad de Valencia, Ajuntamiento de Valencia: València, 253, 2001.

[8] Guallart, V., Sociópolis : Project for a City of the Future, Actar: Barcelona, 256, 2004.

[9] Hough, M., Cities and Natural Process, Routledge: London, 306, 1995.

[10] Gobster, P.H., Nassauer, J.L. \& Daniel, T.C., The shared landscape: what does aesthetics have to do with ecology? Landscape Ecology, 22, pp. 959-972, 2007. http://dx.doi.org/10.1007/s10980-007-9110-x

[11] Batlle, E., El verd urbà modern: art, agricultura i ecologia, In El verd urbà : com i per què?, ed. S. Rueda, Fundació Territori i Paisatge: Barcelona, pp. 70-97, 2007. 